\title{
Bibliography of Professor Brouwer
}

Brouwer, R., 1953. The arrangement of the vascular bundles in the nodes of the Dioscoreaceae. Acta bot. neerl. 2: 66-73.

Brouwer, R., 1953. Waterabsorption by the roots of Vicia faba at various transpiration strengths. I. Analysis of the uptake and the factors determining it. Proc. Kon. Ned. Ak. Wet., Ser. C56, pp. 106-115. II. Causal relations between suction tension, resistance and uptake. Proc. Kon. Ned. Akad. Wet., Ser. C56, pp. 129136. III. Changes in water conductivity artificially obtained. Proc. Kon. Ned. Ak. Wet., Ser. C57, pp. 68-80.

Brouwer, R., 1953. Transpiration and anion uptake. Proc. Kon. Ned. Ak. Wet., Ser. C56, pp. 639-649.

Brouwer, R., 1954. The regulating influence of transpiration and suction tension on the water and salt uptake by the roots of intact Vicia faba plants. Acta bot. neerl. 3: 264-312 (thesis).

Brouwer, R., 1955. De wateropname door de wortel. De plantenwortel in de landbouw. Ministerie van Landbouw, Veeteelt en Visserij, pp. 79-89.

Baerends, G. P., R. Brouwer \& H. Tj. Waterbolk, 1955. Ethological studies on Lebistes reticulatus. I. An analysis of the male courtship pattern. Behaviour 8: 249334.

Brouwer, R., 1956. Radiation intensity and transpiration. Neth. J. agric. Science 4: 43-48.

Brouwer, R., 1956. Water uptake from water and salt solutions. Acta bot. neerl. 5: 268-276.

Brouwer, R., 1956. Investigations into the occurrence of active and passive components in the ion uptake by Vicia faba. Acta Bot. neerl. 5: 287-314.

Brouwer, R., 1959. De invloed van de temperatuur op de ontwikkelingscyclus van erwten. Jaarb. IBS 1959 , pp. 17-26.

Brouwer, R. 1959. De invloed van de worteltemperatuur op de groei van erwten. Jaarb. IBS 1959, pp. 27-36.

Brouwer, R., 1960. De invloed van de aeratie van het wortelmilieu op de groei van bruine bonen. Jaarb. IBS 1960, pp. 11-21.

Brouwer, R. \& G. van Vliet, 1960. De invloed van de worteltemperatuur op de groei en opname bij erwten. Jaarb. IBS 1960, pp. 23-36.

Brouwer, R., 1961. Water transport through the plant. Jaarb. IBS 1961, pp. 11-24.

Brouwer, R. \& P. J. Clarys, 1961. The influence of the pF of sandy soil and clay soil on leaf growth of young barley seedlings. Jaarb. IBS 1961, pp. 25-27.

Brouwer, R., P. J. Jenneskens \& G. J. Borggreve, 1961. Growth responses of shoots and roots to interruptions of the nitrogen supply. Jaarb. IBS 1961, pp. 2936.

1 Instituut voor Biologisch en Scheikundig Onderzoek van Landbouwgewassen Wageningen. 
Brouwer, R. \& E. A. Loen, 1962. Growth and uptake of individual crown roots of Zea mays L. Jaarb. IBS 1962, pp. 19-25.

Brouwer, R., 1962. Influence of temperature of the root medium on the growth of seedlings of various crop plants. Jaarb. IBS 1962, pp. 11-18.

Brouwer, R., 1962. Distribution of dry matter in the plant. Neth. J. agric. Sci. 10: 361-376.

Brouwer, R., 1962. Nutritive influences on the distribution of dry matter in the plant. Neth. J. agric. Sci. 10: 399-408.

Brouwer, R., 1963. Some physiological aspects of the influence of growth factors in the root medium on growth and dry matter production. Jaarb. IBS 1963, pp. 1130 .

Brouwer, R., 1963. Some aspects of the equilibrium between overground and underground plant parts. Jaarb. IBS 1963, pp. 31-39.

Brouwer, R., 1963. The influence of the suction tension of the nutrient solutions on growth, transpiration and diffusion pressure deficit of bean leaves (Phaseolus vulgaris). Acta bot. neerl. 12: 248-261.

Brouwer, R., 1964. Responses of bean plants to root temperatures. I. Root temperatures and growth in the vegetative stage. Jaarb. IBS 1964, pp. 11-22.

Brouwer, R. \& A. Hoogland, 1964. Responses of bean plants to root temperatures. II. Anatomical aspects. Jaarb. IBS 1964, pp. 23-31.

Locher, J. Th. \& R. Brouwer, 1964. Preliminary data on the transport of water, potassium and nitrate in intact and bleeding maize plants. Jaarb. IBS 1964, pp. 4149.

Alberda, Th., W. Louwerse \& R. Brouwer, 1964. The relation between salt and water uptake with intact and decapitated tomato plants. Jaarb. IBS 1964, pp. 6176.

Brouwer, R., 1965. Root growth of grasses and cereals. In: The growth of cereals and grasses. University of Nottingham, pp. 153-166.

Locher, J. Th. \& R. Brouwer, 1965. Influence of different root temperatures on transpiration and exudation of young maize plants. Jaarb. IBS 1965, pp. 57-63.

Brouwer, R., 1965. Ion absorption and transport in plants. Ann. Rev. Pl. Physiol. 16: 241-266.

Brouwer, R., 1965. Water movement across the root. In: The state and movement of water in living organisms. Proc. 19th Symp. Soc. Exp. Biol. Cambridge University Press, London.

Brouwer, R. \& A. Kleinendorst, 1965. Effect of root excision on growth phenomena in perennial ryegrass. Jaarb. IBS 1965, pp. 11-20.

Brouwer, R. \& J. T. Locher, 1965. The significance of seminal roots in growth of maize. Jaarb. IBS 1965, pp. 21-28.

Kleinendorst, A. \& R. Brouwer, 1965. The effect of temperature on two different clones of perennial ryegrass. Jaarb. IBS 1965, pp. 29-39.

Alberda, Th., R. Brouwer, W. H. van Dobben, F. Wit \& C. T. de Wit, 1966. De groene aarde. Het Spectrum, Utrecht, pp. 115-232.

Brouwer, R., 1966. Ecological Physiology of Crop Plants. Agr. Course 313. Agricultural Dept., Cornell University, pp. 223. 
Brouwer, R. \& A. Kleinendorst, 1967. Responses of bean plants to root temperatures. III. Interactions with hormone treatments. Jaarb. IBS 1967, pp. 11-28.

Kleinendorst, A. \& R. Brouwer, 1967. Responses of two different clones of perennial ryegrass to aeration of the nutrient solution. Jaarb. IBS 1967, pp. 29-38.

Brouwer, R., 1967. Beziehungen zwischen Spross- und Wurzelwachstum. Angew. Bot. 41: 244-254.

De Wit, C. T. \& R. Brouwer, 1968. Über ein dynamisches Modell des vegetativen Wachstums von Pflanzenbestanden. Angew. Bot. 42: 1-12.

Brouwer, R. \& J. A. Huyskes, 1968. A physiological analysis of the responses of the lettuce variety 'Rapide' and its hybrid with 'Hamadan' to day-length and light intensity. Euphytica 17: 245-251.

Brouwer, R. \& C. T. de Wit, 1968. A simulation model of plant growth with special attention to root growth and its consequences. In: W. J. Whittington (Ed.), Root growth. Proc. 15th Easter School in Agricultural Science, University of Nottingham, pp. 224-244.

Brouwer, R., 1968. De groeifactor stikstof en de produktie. In: Landbouwplantenteelt 1968, pp. 44-67.

Brouwer, R. \& E. Levi, 1969. Responses of bean plants to root temperatures. IV. Translocation of ${ }^{22} \mathrm{Na}$ applied to the leaves. Acta bot. neerl. 18: 58-66.

Brouwer, R., A. Kleinendorst \& J. Th. Locher, 1970. Growth responses of maize plants to temperature. Proc. Uppsala Symp.: 169-174.

Brouwer, R., 1968. Morphological and physiological adaptations to external conditions. Acta bot. neerl. 17: 78-80.

Kleinendorst, A. \& R. Brouwer, 1970. The effect of temperature of the root medium and of the growing point of the shoot on growth, water content and sugar content of maize leaves. Neth. J. agric. Sci. 18: 140-148.

De Wit, C. T., R. Brouwer \& F. W. T. Penning de Vries, 1970. A dynamic model of plant and crop growth. In: Prediction and measurement of photosynthetic productivity. Proc. IBP/PP Technical Meeting, Trebon, 1969. Pudoc, Wageningen, pp. 117-142.

De Wit, C. T., R. Brouwer, \& F. W. T. Penning de Vries, 1970. The simulation of photosynthetic systems. In: Prediction and measurement of photosynthetic productivity. Proc. IBP/PP Technical Meeting, Trebon, 1969. Pudoc, Wageningen, pp. 47-71.

Visser, J., J. Th. Locher \& R. Brouwer, 1971. Effects of aeration and mineral supply on growth and mineral content of shoots and roots of apple trees (var. 'Golden Delicious' on M IX). Neth. J. agric. Sci. 19: 125-137.

Wesselius, J. C. \& R. Brouwer, 1972. Influence of water stress on photosynthesis respiration and leaf growth of Zea mays L. Meded. Landbouwhogesch. Wageningen 72-33: 1-15.

Brouwer, R. \& P. J. C. Kuiper, 1972. Leerboek der Plantenfysiologie, Vol. 3: Oecofysiologische relaties. Oosthoek, Utrecht.

Brouwer, R., 1973. Dynamics of plant performance. Proc. Int. Soc. hort. Sci. 38: 31-49.

Brouwer, R., 1973. Plant physiology and ecology. Acta bot. neerl. 19: 260-261. 
Brouwer, R., 1974. A comparison of the effect of drought and low root temperature on leaf elongation and photosynthesis in maize. Proc. Int. Soc. hort. Sci. 39: 141-152.

Brouwer, R. \& L. K. Wiersum, 1977. Root aeration in relation to crop growth. In: U. S. Gupta (Ed.), Crop Physiology, Oxford and TBH Publishing Co., pp. 138166.

Brouwer, R., 1977. Root Functioning. In: J. J. Landsberg \& C. V. Cutting (Eds.), Environmental effects on crop physiology. Academic Press, New York, pp. 229245.

Brouwer, R., 1977. The effect of soil waterlogging on various physiological processes in maize. Phytotronic Newsletter 15: 75-80.

Brouwer, R., 1978. Soil physical conditions and plant growth. Verh. Kon. Ned. Akad. Wet. 2e reeks, 70: 189-213.

Brouwer, R., 1981. Effects of environmental conditions on root functioning. Acta Hortic. 119: 91-96.

Brouwer, R., 1981. Co-ordination of growth phenomena within a root system of intact maize plants. Plant and Soil 63: 65-72.

Brouwer, R., 1982. In: D. Stegwee \& A. Quispel (Eds.), Leerboek der plantenfysiologie. Bohn, Scheltema en Holkema, Deventer, pp. 247-266, 285-296, 395 404. 